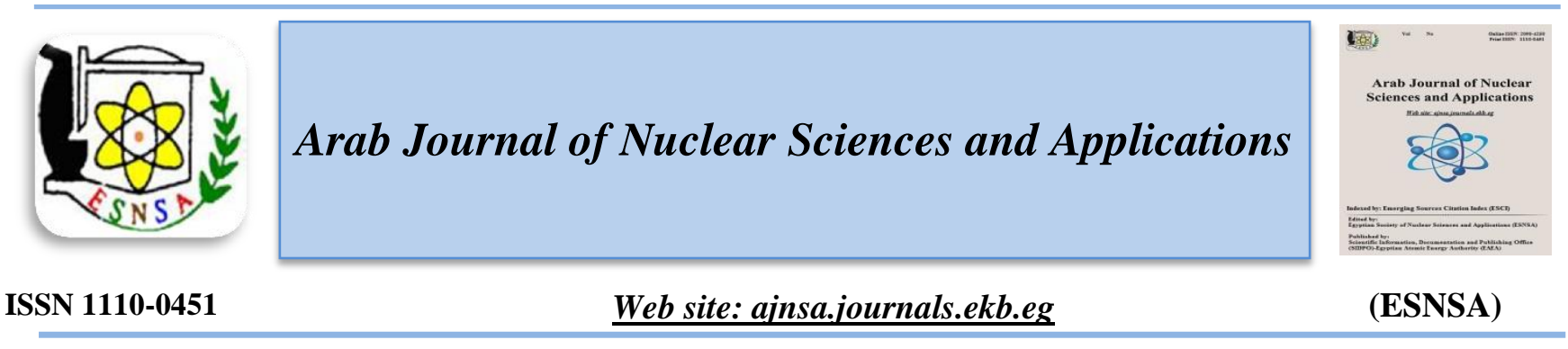

\title{
Rheological Assessment of Different Bread Wheat Genotypes Induced via Radiation and Hybridization
}

\author{
M. A. Abdelaleem* and K. F. Al-Azab \\ Plant Research Department, Nuclear Research Center, Atomic Energy Authority, Egypt
}

\begin{abstract}
Received $3^{\text {rd }}$ Feb. 2020 The present study aims to evaluate the physicochemical and rheological properties of flour samples for Accepted $5^{\text {th }}$ Aug. 2020 six commercial Egyptian bread wheat types (two commercial varieties namely Giza-168 and Gemmeiza11, and four promising lines namely L84, L148, M10, and M34). The sample of M10 which was induced/mutated by gamma radiation at a dose of $350 \mathrm{~Gy}$, showed the best physicochemical and rheological properties. The sample's ash, protein, wet gluten, gluten index, falling number, extraction percentage, and Zeleny value were $0.63,14.1 \%, 36.4 \%, 87 \%, 567$ sec., $83.8 \%$ and $58 \%$, respectively. The farinograph parameters: water absorption $(65.8 \%)$, dough development time (11 min) and dough stability $(10.8 \mathrm{~min})$ were significantly $(P<0.05)$ higher in the M10 samples compared to all other samples under study. Furthermore, the alveograph parameters showed the highest tenacity $(142 \mathrm{~mm})$, dough extensibility $(107 \mathrm{~mm})$ and dough deformation energy $\left(499 \mathbf{1 0}^{-4} \mathrm{~J}\right)$. Thus, the promising sample induced via gamma radiation (M10) was the best in terms of all parameters in bread making.
\end{abstract}

Keywords: bread wheat, rheology, farinograph, alveograph, radiation mutation

\section{Introduction}

Rheology measurements are considered the most valuable methods to assess the quality of flour, their parameters are designed to monitor the molecular structure, mechanical properties, material composition and to anticipate the quality of end product [1]. Determination of different flour properties, which influence the properties of dough and its behavior during processing, is called technological quality of wheat flour. Physical, chemical and rheological parameters are the most commonly used tests in determining empirical (descriptive, imitative) methods. These rheological tests include farinograph, extensograph, alveograph, amylograph and Mixograph [2]. Protein content, Zeleny index, fall/decrease index, wet gluten, extensibility, and resistance are considered the physiochemical quality parameters of dough flour, which composed as the results of highly complex interactions that need to be usually judged [3]. In addition, rheological characterization of dough is an effective behavior in monitoring, predicting and controlling the quality of wheat products $[4,5]$.

Regarding the empirical rheological parameters, the determination of the flour quality is possible using farinograph and alveograph, which are used for characterizing dough rheology [6]. These instruments give full imaging and information for the baking industries [7]. Both farinograph and Mixograph illustrated full information about mixing characteristics of flour i.e.; dough development time, dough stability, and water absorption while, extensograph and alveograph represented gluten extensibility and keiffer dough

Corresponding author: Abdelrazek_md@yahoo.com

DOI: 10.21608/ajnsa.2020.23450.1326

CScientific Information, Documentation and Publishing Office (SIDPO)-EAEA 
i.e.; resistance to extension, dough strength, and dough deformation energy [6].

Quantity and quality of protein are mainly characterized by both environmental and genetics factors. Protein quality is based on the consideration of the potential end use rather than nutritional characteristics. A flour of good quality for bread-making should have high water absorption, a medium to medium - long mixing requirement, satisfactory mixing tolerance, and bread volume potential (considering protein content), and the loaf should have a good color and internal grain. Bread-making is largely affected by the quantity and quality of its protein. Thus, the higher the protein quality, the best the bread could be baked. Even if the content of protein is high, but has poor quality, the poor wheat will yield low quality bread [8].

In this study, flour of six genotypes of Egyptian bread wheat was analyzed for sets of physicochemical and rheological parameters. Empirical rheological characterization including empirical methods such as farinograph and alveograph were used in our investigation. The aim of our investigation was to evaluate the rheological and baking properties of promising wheat lines derived via hybridization and gamma irradiation.

\section{Materials and Methods}

This investigation was carried out at the experimental farm of the Plant Research Department, Nuclear Research Center, Inshas, Egypt during the two successive wheat growing seasons 2016/2017 through 2017/2018. The soil at the experimental site was loamy sand to sandy. Rainfall in both seasons was very light.

\section{Materials}

Six bread wheat (Triticum aestivum L.) genotypes, two Egyptian commercial varieties namely; Giza168 (Gz168) [pedigree, Mrl / Buc // Seri CM 930468M-0Y-0M-2Y-0B] and Gemmeiza-11 (Gm11) [pedigree, BOW"S"/KVZ"S"// 7C/SERI82/3/GIZA168/SKHA61], and four promising lines; two lines via hybridization L84 [pedigree, Sids $4 \times$ Giza-168] and L148 [pedigree, Maryout-5 $\times$ Giza-168], and two lines via radiation mutation M10 [pedigree, Sids-4/350Gy ], and M34 [Aseel-5/350Gy] developed by the wheat breeding program of the Atomic Energy Authority, Inshas, Egypt (Al-Azab-2013) were used in this investigation.
Methods

The seeds from each of the six genotypes were sown in the field under well water conditions in a randomized complete block design (RCBD) with three replications; each experimental plot consisted of six rows for each genotype. The rows were $4 \mathrm{~m}$ long and $25 \mathrm{~cm}$ wide and spaces between plants were $10 \mathrm{~cm}$ within each row. The seeding rates was about 300 seeds $/ \mathrm{m}^{2}$.

The wheat grain samples were milled on a Chopin laboratory mill. Before being milled, the grain samples were conditioned to $14.0 \%$ moisture for 20-24 hours. Moisture and protein content for wheat after conditioning were analyzed using Perten IM9500, Sweden and extraction rate among six wheat traits were all presented in Table (1).

\section{Evaluation of physiochemical properties of wheat flour}

Wheat flour analyses (Table, 1) were performed using (Perten, Sweden) and evaluated according to AACC [9]. These quality tests of wheat flour were as follows; protein content (AACC 46-12), moisture (AACC 44-16), ash (AACC, 08-01), wet gluten (AACC 38-12 A), gluten index (AACC 3812 A) falling number (AACC 56-81 B), Zeleny sedimentation value (AACC 56-60) and color ( $\left.\mathrm{L}^{*}\right)$ as well as, extraction rate $(\%)$ of all bread wheat genotypes under study.

\section{Empirical rheology measurements}

Dough rheological analyses consisted of flour (100 $\mathrm{g})$, salt (1.8 g) and water were analyzed according to AACC [9] using the following empirical rheological methods farinograph (AACC 54-21) and alveograph (AACC 54-30).

The following parameters were determined in a Brabender farinograph: water absorption (WA, percentage of water required to yield dough consistency of $500 \mathrm{BU}$ (Brabender Units)), dough development time (DDT, time to reach maximum consistency), dough stability (DS, time during dough consistency is at $500 \mathrm{BU}$, between arrival time and departure time), degree of softening ( $\mathrm{S}$, the distance between the center of the mixing curve and the 500-BU line after 20 min. mixing), arrival time (the time when the top of the curve touches the 500-BU line), departure time (the time when the top of the curve leaves the 500-BU line). Alveograph test was performed using an alveograph (Chopin CD-1) following the AACC method (54-30A) [9]. 
The following alveograph parameters were automatically recorded using a computer software program: tenacity or resistance to extension $(\mathrm{P}$, $\mathrm{mm} \mathrm{H}_{2} \mathrm{O}$ ), dough extensibility ( $\left.\mathrm{L}, \mathrm{mm}\right)$, curve configuration ratio $(\mathrm{P} / \mathrm{L})$, deformation energy $(\mathrm{W}$, $\left.10^{-4} \mathrm{~J}\right)$, swelling index $(\mathrm{G})$ and elasticity index (Ie, \%).

\section{Statistical Analysis}

The results were expressed as the mean of three replicates. The data were statistically analyzed using SAS ${ }^{\circledR} 9.2$ software [10]. The general linear model procedure was applied and Duncan's multiple range test was used to compare the mean values at $\mathrm{P}<0.05$, probability level.

\section{Results and Discussion \\ Wheat quality}

As shown in Table (1), the protein content in the mutated genotypes of bread wheat (M10 and M34) was significantly $(\mathrm{P}<0.05)$ increased compared to control (G-168 and G-11). While, line L48 did not show a significant increase. Furthermore, the moisture content did not show great differences among wheat genotypes under study. Wheat breeders and flour millers used weighing method to assess wheat composition and flour extraction. However, the higher the Thousand kernel weight (TKW), the greater was the potential flour extraction that can be expected [11].

\section{Broad-sense heritability $\left(h_{b s}^{2}\right)$}

The heritability values estimated for traits of interest are given in Table (1). They ranged from $65.1 \%$, for Thousand kernel weight (TKW), to $99.5 \%$, for Protein content. The $\mathrm{h}^{2}$ bs values ranged from high to very high values for all of the characteristics studied due to smaller environmental variance, indicating that the genetic variance is the main component of phenotypic variance and that the environment had low effect on the phenotype. On the average, the highest $\mathrm{h}^{2}$ bs estimate $(99.5 \%)$ was shown by Protein content followed by moisture $(88.0 \%)$ and grain yield $(85.7 \%)$, in descending order.

\section{Physiochemical characteristics of wheat flour}

The quality of wheat is the reflection of environmental aspects including soil, seed stock and climate on the wheat kernel components. Mainly, the quality of wheat grain affects the quality of end product furthermore. Wheat has so many varieties, the suitability of a certain wheat variety for specific use may be unsuitable for another use. All data in the present study revealed that, there were great significant $(\mathrm{p}<0.05)$ differences among six wheat samples in all the studied parameters. These findings follow the same trend of the findings reported by Stathopoulos et al. [12], they found that flour physicochemical and rheological properties were differed significantly among wheat varieties.

Table (2) shows the physicochemical compositions of six different wheat flours. These flours showed significant $(p<0.05)$ differences in their composition. The mineral content of endosperm is very low compared to outer bran layers. So, low grade flour, rich in powdered bran give higher ash content (an index of mineral content of flour) in comparison with refined or patent flours. Both promising via hybridization (L84 and L148) and mutated ones (M10 and M34) showed significant $(\mathrm{P}<0.05)$ increase in the ash content compared to the control (Gz168 and Gm11).

Table (1): Filed and physicochemical characteristics of different wheat samples

\begin{tabular}{cccccccc}
\hline & ${ }^{1} \mathbf{L 8 4}$ & ${ }^{1} \mathbf{L 1 4 8}$ & ${ }^{2} \mathbf{M 1 0}$ & ${ }^{2} \mathbf{M 3 4}$ & ${ }^{3} \mathbf{G z 1 6 8}$ & ${ }^{3} \mathbf{G m 1 1}$ & $\mathbf{h}^{\mathbf{2}}{ }_{\mathbf{b s}} \% *$ \\
\hline Moisture \% & $9.2^{\mathrm{a}}$ & $9.3^{\mathrm{ab}}$ & $9.9^{\mathrm{d}}$ & $9.5^{\mathrm{bc}}$ & $9.6^{\mathrm{c}}$ & $9.4^{\mathrm{bc}}$ & 88.0 \\
$\begin{array}{c}\text { Protein \% (on db) } \\
\text { Thousand kernel }\end{array}$ & $15.1^{\mathrm{d}}$ & $14.5^{\mathrm{c}}$ & $15.0^{\mathrm{d}}$ & $16.0^{\mathrm{e}}$ & $12.8^{\mathrm{b}}$ & $12.1^{\mathrm{a}}$ & 99.5 \\
$\begin{array}{c}\text { weight (g) } \\
\text { Grain yield }\left(\mathbf{k g} / \mathbf{m}^{2}\right)\end{array}$ & $0.57 .0^{\mathrm{a}}$ & $55.0^{\mathrm{a}}$ & $51.0^{\mathrm{b}}$ & $45.0^{\mathrm{c}}$ & $46.0^{\mathrm{bc}}$ & $54.0^{\mathrm{a}}$ & 65.1 \\
\hline
\end{tabular}

* Heritability; ${ }^{1}$ Lines developed via hybridization, ${ }^{2}$ Mutants developed via gamma radiation, ${ }^{3}$ Cultivars as control; Values are means of three replicates; values followed by different letters in the same row are significantly different (P $<0.05)$ using Duncan test. 
The higher the extraction rate are get, the higher the protein, the ash content and the lower the moisture content were get [13].

The data in Table (2) showed that the extraction rate of all bread wheat genotypes was significantly $(\mathrm{P}<0.05 \%)$ different. M10 showed the highest extraction rate $(83.8 \%)$, protein content $(14.1 \%)$ and ash content $(0.63 \%)$ compared with all samples. These data are in agreement with those of Moradi et al. [14] who found that when the extraction rate, amount of protein, fiber, fat and ash increased, moisture content decreased.

Falling number is the enzyme activity in wheat or flour measured as seconds, where higher falling number indicates a low enzymes activity while the low falling number indicates a high enzyme activity, which commonly occurs due to weather damage. Rain damage and germination of grains lead to produce $\alpha$-amylase enzyme which negatively impacts on end-product performance [15]. The increase in $\alpha$-amylase dose breaks down starch into sugars and reduces the dough stability [16].

However, the falling number value on $14 \%$ moisture basis was above $300 \mathrm{sec}$ in all samples under study (Table, 2). Falling number above 300 sec indicates minimal enzyme activity and sound quality wheat or flour. On the contrary, a falling number below $250 \mathrm{sec}$ indicates a substantial enzyme activity and sprout-damaged wheat or flour. Another study on the falling number revealed that the standard falling number values were between 200 and $300 \mathrm{sec}$. In this range, there is an ideal enzymatic activity possessing an optimum volume of bread. Otherwise, above 300 sec the bread is reduced in volume but the quality does not change [17].

Mutation treatment in our present study was done in order to induce bread wheat seeds via gamma radiation at dose $350 \mathrm{~Gy}$. The radiation mutation might be inducing seeds to reduce the enzymatic activity thus, the falling number increased in samples M10. While, Teixeira et al. [18] studied the effect of irradiation treatment on wheat flour and they found that the increase of enzymatic activity or reduced falling number (per seconds) is due to an increment of the irradiation dose.

Protein content is an important indication for wheat and flour quality since it is related to many processing properties, i.e.; water absorption and gluten strength. Moreover, protein content can also be the most important factor for determining the quality of flour where higher protein content causes higher quality of the final product attributes, i.e.; texture and appearance $[19,20]$. The protein content is varied depending on types of bakery products where, crisp or tender products need low protein content and chewy texture products (pan bread and health bread) need a high protein content [17].

As shown in Table (2) the protein content was significantly $(\mathrm{P}<0.05)$ higher in samples M10 (14.1\%), M34 (13.7\%), L148 (14.3\%) and L84 (13.3\%) compared to control sample [Gz168 $(11.7 \%)$ and $\mathrm{Gm} 11(10.7 \%)]$. Both the quality and quantity of protein affects water absorption [21, $22,23]$. As clearly obvious in Table (3), water absorption is directly increased as the protein content increased (Table, 2), where water absorption in Table (3) was increased significantly $(\mathrm{P}<0.05)$ in samples M10, L84 and L148 compared to control samples (Gz168 and Gm11). The obtained data are in the line with the findings of Hefnawy et al. [24] who found that the increase in water absorption is related to an increase in protein content. Moreover, the protein percentage varied among varieties of bread wheat. Regarding protein content of wheat flour, the flour is used in; bread making, pasta product and biscuit making, when the protein content is $(14-16 \%),(12-$ $14 \%)$ and $(7-12 \%)$, respectively.

Wheat flours show great diversity in their functional characteristics due to their diversity of classes and cultivars. These variations are attributed largely to its gluten quality and quantity, where gluten is mainly responsible for extensibility and elasticity [25]. About $80-85 \%$ of the total protein flour content is gluten and functions as wheat storage proteins [26]. Mixing with water makes gluten swell and reflect protein content thus, give the specification required by end-users and bakers in the food and bakery industries [17, $26,27]$. Table (2) shows that the wet gluten of all samples under study possesses strong gluten wheat, except the control samples (Gz168 and Gm11) where the wet gluten contents were $30.8 \%$ and $27.3 \%$, respectively. Many studies recorded that the gluten content varies from $20 \%$ to $42 \%$. where, the high percentage of protein content above $35 \%$ showed a strong gluten wheat while, the low protein content below $23 \%$ showed a weak gluten wheat [17].

There is a relation between the baking strength and the hydration capacity where it determines the 
baking quality as well. The Zeleny test is also considered a rapid test for baking quality estimation. In addition, the Zeleny sedimentation test was directly correlated to the protein content, thus, it is used as a screening tool in wheat breeding and milling applications [1, 11]. The Zeleny sedimentation test was recorded, samples subjected to radiation mutation (M10 and M34) were the highest in Zeleny levels in all samples under investigation. As a point of view, radiation mutation might have induced protein composition that led to the variation of the Zeleny levels varied in mutated samples from promising lines and control samples. The same finding was reported by Hrušková et al. [8] who found that the Zeleny value of flour depends on the wheat protein composition in addition to protein content. Hrušková and Famêra [8] found that the higher the gluten content, the better gluten quality we get, the slower sedimentation, the higher Zeleny test values we have. So, our obtained data are in a complete agreement with these findings. As reported by Shelton [11], the color value of typical while ( $\mathrm{L}^{*}$, whiteness) flour was +92.5 . Table (2) shows that the color significantly differed in wheat flour samples comes from radiation mutation M10 (+89.3) and M34 (+89.6) compared to control samples Gm11 (+90.9) and Gz168 (+ 90.1).

\section{Empirical rheological properties of wheat flour}

Rheology can be defined as the study of how materials deform, flow or fail when a force is applied. Empirical (descriptive) tests have been used to characterize the behavior of bread dough's during processing, i.e. Farinograph (mixing time/torque), Alveograph (Biaxial extensibility), Extensograph (Extensibility) and Mixograph (Apparent viscosity) [4]. Rheological methods are effective means of checking the flour quality when milling wheat of rather homogeneous compositions. Empirical properties measured as rheological tests (Farinograph an Alveograph) performed on six bread wheat (L84, L148, M10, M34, Gz168 and Gm11) in order to assess their technological quality have shown that there are some differences in the values of specified parameters (Tables 2 and 3) and (Figures. 1 and 2). Regarding the rheological changes, the gluten viscoelastic network during mixing and aeration has importance for product quality, due to the relation between rheology and baking performance. Thus, the aeration, texture, and finally rheology depend on the mixer design [28].

\section{Rheological analysis (Farinograph parameter)}

Farinograph is considered one of the most common tests used in flour quality evaluation where it is basically used in estimating water amount required to make a dough and finally to predict finished product texture properties [5, 29]. Water absorption of different wheat varieties was in ranges from $58.1-66.4 \%$ [30]. As shown in Table (3), the values of farinograph parameters, sample M10 showed the best quality of all samples under study, which was confirmed by the value of the highest water absorption (65.8\%), dough development time (11.0 min), dough stability (10.8 min) and farinograph quality number (104). Promising bread wheat lines (L84 and L148) showed not only extremely high water absorption of $60.3 \%$ and $63.4 \%$, respectively, but also lower values of dough development time (2 and $2.6 \mathrm{~min}$ ) and dough stability (1.2 and $1.4 \mathrm{~min}$ ), which is a good indication of inadequate protein quality to unable retain water inside the dough.

A sample of control bread wheat (Gz168) had also significantly $(\mathrm{P}<0.05)$ higher dough stability compared to other samples under investigation, except sample M10, where, dough stabilities in Gz168, M34, L148, L84 and Gm11 were 5.4, 3.4, 1.4, 1.2 and 1 min., respectively (Table, 3 ).

Generally, a flour with good bread-making characteristics has a higher absorption, takes longer times to mix, and is more tolerant to over mixing than biscuit quality flour. The obtained data of farinogram illustrated in Figure (1) showed that, flours from radiation mutation bread wheat (M10 and M34) harvested in seasons 2016/2017 and 2017/2018 were assessed as stronger gluten flour with higher water absorption, longer time of development and dough stability. On the contrary, farinograms in Figures (1a and 1c), were marked as weaker protein flour in the sample of the promising line (L148) and control (Gm11). Bakers depend on the protein content in accurately determining water absorption as well as, dough development time where, as protein increased the mixture requires more water to get optimum dough consistency [11].

Dough development time (DDT) is defined as the time from the first water addition to the time when the dough reaches the point of consistency (550 
BU). So, during this time the flour components are hydrated by water and then the dough is developed. DDT was in the range of $1.5-13.0 \mathrm{~min}$ which indicated that tested flour samples had different levels of gluten structure compactness [31].

Bread wheat of M10 genotype showed the highest dough strength properties based on Farinograph results. Both Farinograph DDT and dough stability (DS) was $11 \mathrm{~min}$. and $10.8 \mathrm{~min}$, respectively (Table 3). Dough development time (DDT) and dough stability value, the important parameters in estimating protein quality, are indicators of the flour strength, higher values suggesting stronger doughs [32].

\section{Rheological analysis (Alveograph parameter)}

Alveograph is one of the most common devices determining biaxial extensibility to provide millers with all parameters of strong and weak gluten flour [5]. Biaxial extension is where a material is stretched at equal rates in two perpendicular directions in one plane. The test measures and records over time, the pressure inside a bubble formed by inflating a dough test piece to the point of rupture [1]. It can also, measure the resistance to deformation and extensibility of a clamped discshaped piece of dough by forming a bubble using air pressure applied from below the dough piece. This rheological test is used to predict the suitability of flours for use in end products [15].

The flour rheological properties, measured with an alveograph, appeared to be well balanced as far as extensibility and elasticity are concerned. The Alveograph properties presented in Table (3) showed that there were significant differences $(\mathrm{P}<0.05)$ in flour samples among the parameters of alveograph. Dough resistance to deformation or tenacity $(\mathrm{P})$ is the ability to predict how the dough retained gas where, as the bran increased, $\mathrm{P}$ increased [33]. In samples M10, M34 and L148, the resistance to deformation $(\mathrm{P})$ increased significantly $(\mathrm{P}<0.05)$ compared to other samples.

Table (2): Proximate physicochemical composition and rate of extraction of different wheat flour ${ }^{\text {a }}$

\begin{tabular}{|c|c|c|c|c|c|c|c|c|c|}
\hline Genotypes & Moisture (\%) & $\begin{array}{c}\text { Ash (\%) } \\
\text { (on db) }\end{array}$ & $\begin{array}{c}\text { Protein (\%) } \\
\text { (on db) }\end{array}$ & Wet Gluten (\%) & Gluten index (\%) & Color $\left(L^{*}\right)$ & Falling Number (sec) & $\begin{array}{c}\text { Zeleny } \\
\text { (ml) }\end{array}$ & $\begin{array}{c}\text { Extraction } \\
(\%)\end{array}$ \\
\hline L84 & $13.5^{\mathrm{a}}$ & $0.54^{\mathrm{a}}$ & $13.3^{b}$ & $39.3^{\mathrm{e}}$ & $35^{\mathrm{a}}$ & $90.2^{\mathrm{ab}}$ & $376^{a}$ & $49^{b}$ & $58.1^{\mathrm{b}}$ \\
\hline L148 & $14.5^{\mathrm{c}}$ & $0.63^{c}$ & $14.0^{\mathrm{b}}$ & $35.1^{\mathrm{c}}$ & $55^{b}$ & $89.4^{\mathrm{a}}$ & $358^{b}$ & $55^{\mathrm{c}}$ & $71.5^{\mathrm{d}}$ \\
\hline M10 & $14.3^{\mathrm{c}}$ & $0.63^{\mathrm{c}}$ & $14.1^{b}$ & $36.4^{\text {cd }}$ & $87^{c}$ & $89.3^{\mathrm{a}}$ & $567^{\circ}$ & $58^{\mathrm{c}}$ & $83.8^{\mathrm{f}}$ \\
\hline M34 & $13.4^{\mathrm{a}}$ & $0.60^{b}$ & $13.7^{\circ}$ & $37.2^{\mathrm{d}}$ & $61^{\mathrm{d}}$ & $89.6^{\mathrm{a}}$ & $434^{d}$ & $57^{c}$ & $67.4^{c}$ \\
\hline Gz168 & $13.9^{\mathrm{b}}$ & $0.62^{\mathrm{bc}}$ & $11.1^{\mathrm{a}}$ & $30.8^{b}$ & $45^{\mathrm{e}}$ & $90.1^{\mathrm{ab}}$ & $458^{\mathrm{e}}$ & $45^{\mathrm{a}}$ & $79.1^{\mathrm{e}}$ \\
\hline Gm11 & $13.5^{\mathrm{a}}$ & $0.53^{\mathrm{a}}$ & $10.7^{\mathrm{a}}$ & $27.3^{\mathrm{a}}$ & $70^{f}$ & $90.9^{b}$ & $387^{\mathrm{f}}$ & $43^{\mathrm{a}}$ & $43.3^{\mathrm{a}}$ \\
\hline
\end{tabular}

${ }^{a}$ Expressed on $14 \%$ moisture basis; $L^{*}=$ whiteness (100 white to 0 black); Values are means of three replicates; values followed by different letters in the same column are significantly different $(\mathrm{P}<0.05)$ using Duncan's test.

Table (3): Farinograph and alveograph parameters of different wheat flour

\begin{tabular}{|c|c|c|c|c|c|c|c|c|c|c|c|}
\hline & \multicolumn{5}{|c|}{ Farinograph parameters } & \multicolumn{6}{|c|}{ Alveograph parameters } \\
\hline & $\begin{array}{l}\text { WA } \\
(\%)\end{array}$ & $\begin{array}{l}\text { DDT } \\
(\mathrm{min})\end{array}$ & $\begin{array}{c}\text { DS } \\
\text { (min) }\end{array}$ & $\begin{array}{c}\mathrm{S} \\
(\mathrm{BU})\end{array}$ & $\begin{array}{l}\text { FQN } \\
(\mathrm{mm})\end{array}$ & $\begin{array}{c}P \\
(\mathrm{~mm})\end{array}$ & $\begin{array}{c}\text { L } \\
(\mathrm{mm})\end{array}$ & $\begin{array}{c}\text { P/L } \\
\text { Ratio }\end{array}$ & $\begin{array}{c}\mathrm{W} \\
\left(10^{-4} \mathrm{~J}\right)\end{array}$ & $\begin{array}{c}\mathbf{G} \\
(\mathrm{mm})\end{array}$ & $\begin{array}{c}\text { Ie } \\
(\%)\end{array}$ \\
\hline L84 & $60.3^{d}$ & $2.0^{\mathrm{a}}$ & $1.2^{2 \mathrm{~b}}$ & $147^{c}$ & $24^{\mathrm{ab}}$ & $59^{a}$ & $89^{c}$ & $0.70^{\mathrm{a}}$ & $128^{\mathrm{a}}$ & $20.3^{c}$ & $38.5^{c}$ \\
\hline Ll48 & $63.4^{e}$ & $2.6^{b}$ & $1.4^{b}$ & $179^{d}$ & $30^{c}$ & $89^{\circ}$ & $67^{\mathrm{b}}$ & $1.33^{\mathrm{ab}}$ & $143^{b}$ & $18.2^{b}$ & $28.8^{b}$ \\
\hline Ml0 & $65.8^{f}$ & $11.0^{\mathrm{d}}$ & $10.8^{e}$ & $231^{f}$ & $104^{e}$ & $142^{\mathrm{d}}$ & $107^{\mathrm{e}}$ & $1.33^{a b}$ & $499 c$ & $23.0^{\mathrm{d}}$ & $59.4^{\mathrm{e}}$ \\
\hline M34 & $58.8^{b}$ & $4.0^{c}$ & $3.4^{c}$ & $129^{a}$ & $59^{d}$ & $88^{c}$ & $71^{b}$ & $1.24^{\mathrm{ab}}$ & $221^{d}$ & $18.7^{b c}$ & $54.0^{\mathrm{d}}$ \\
\hline Gzl68 & $54.4^{\mathrm{a}}$ & $1.9^{\mathrm{a}}$ & $5.4^{d}$ & $139^{b}$ & $22^{a}$ & $78^{b}$ & $47^{a}$ & $1.70^{b}$ & $100^{\mathrm{e}}$ & $15.1^{\mathrm{a}}$ & $18.4^{\mathrm{a}}$ \\
\hline Gmll & $59.9 c$ & $2.1^{\mathrm{a}}$ & $1.0^{2}$ & $185^{e}$ & $26^{b}$ & $57^{\mathrm{a}}$ & $97^{d}$ & $0.59^{a}$ & $174^{f}$ & $21.9^{\mathrm{d}}$ & $51.9^{\mathrm{d}}$ \\
\hline
\end{tabular}


WA = Water Absorption; DDT = Dough Development time; DS = Dough Stability; S = Degree of Softening; FQN $=$ Farinograph Quality Number; BU = Brabender unit; $\mathrm{P}=$ Resistance of deformation (tenacity); L = Dough extensibility; W $=\mathrm{Dough}$ deformation energy; $\mathrm{G}=$ Swelling index; Ie = Elasticity index; Values are means of three replicates; Values followed by different letters in the same column are significantly different $(\mathrm{P}<0.05)$ using Duncan's test.
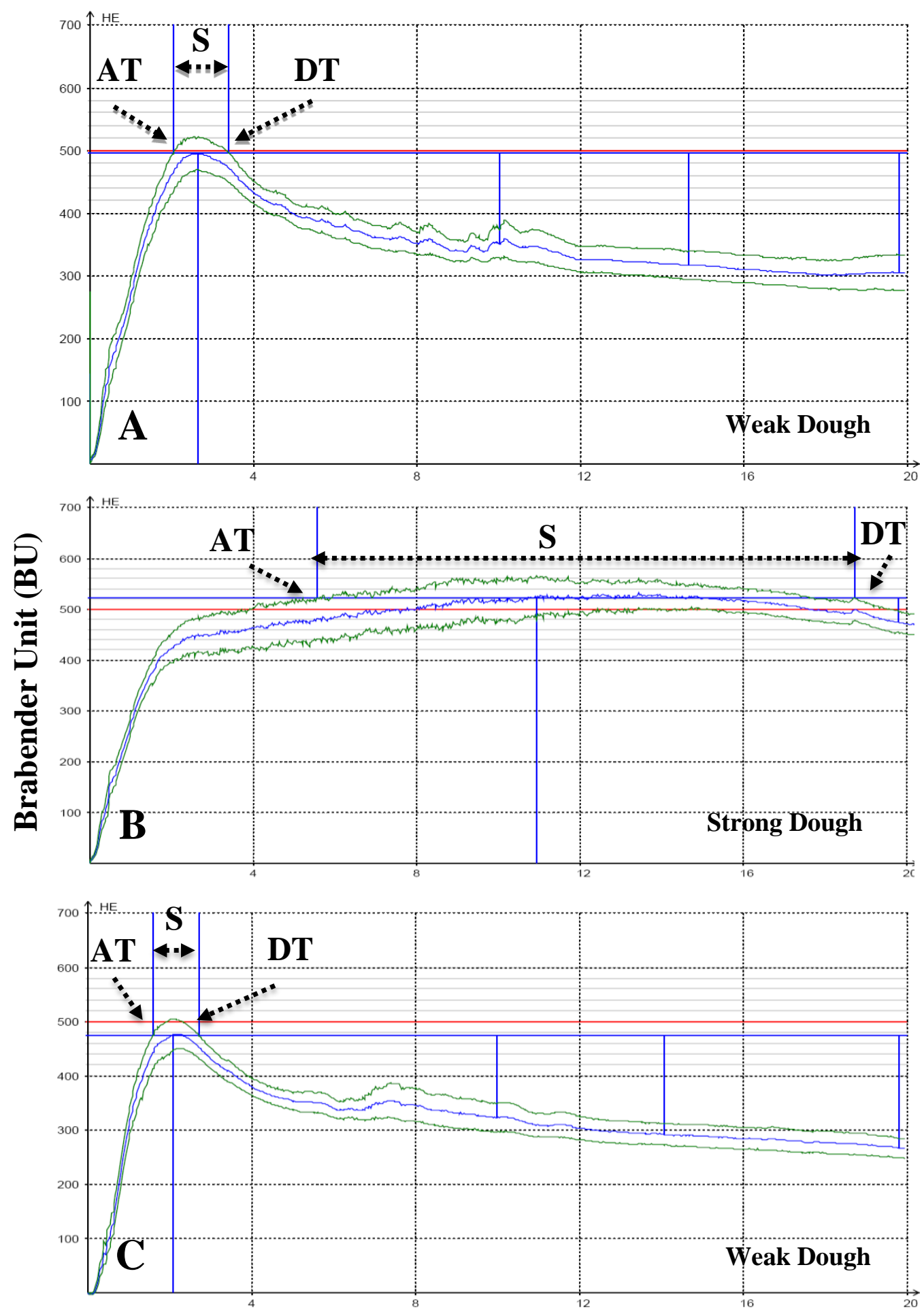

Time (min.)

Fig. (1): Farinogram of (A) hybridized bread wheat line L148, (B) radiation mutation bread wheat M10, (C) control bread Gemmeiza 11 (Gm11), (AT) arrival time, (DT) departure time, (S) stability 
Figure (2) illustrates that the $\mathrm{P}$ values of samples L84 (59 mm) and Gm11 (57 mm) showed a weak wheat quality, sample Gz168 (78 mm) showed standard wheat quality range, samples L148 (89 $\mathrm{mm})$ and M34 (88 $\mathrm{mm})$ introduced very good wheat quality while, the extra strong wheat sample was M10 (134 mm). All previous data were illustrated according to Blakeney et al. [15] who mentioned that the $\mathrm{P}$ values of wheat quality were $60-80 \mathrm{~mm}$ (standard), $80-100 \mathrm{~mm}$ (very strong) and $>100 \mathrm{~mm}$ (extra strong).

Moreover, the extensibility of dough (L value), as an indicator of the handling characteristics of dough, was good in sample M10 (107 mm) as mentioned by Blakeney et al. [15], while the shorter the $\mathrm{L}$ value, the better the wheat quality we have. On the basis of alveogram values, the specific purpose of selecting certain wheat flour is different between different countries depending on the availability of wheat flour with specific quality [34].
The dough deformation energy (W) is a common indicator used in grain trade and prediction of flour processing behavior, where it measures the flour's power as the dough deformation. Table (3) shows the values of energy and the highest value was induced via radiation sample M10 $\left(499,10^{-4} \mathrm{~J}\right)$ which marked a significant $(\mathrm{P}<0.05)$ increase compared to all other samples. The wheat was characterized as: improved wheat when the dough energy was higher than $30010^{-4} \mathrm{~J}$, a good wheat quality is attained when the dough energy ranges from 200 to $30010^{-4} \mathrm{~J}$ and confectionary wheat refers to dough energy below 115 [35].

Irradiation treatment of wheat flour introduces many physicochemical changes in flour of bread wheat [18], where, the higher the irradiation dose, the higher the force of dough deformation. This change occurred because of the increased extensibility generated by the change in gluten structure.

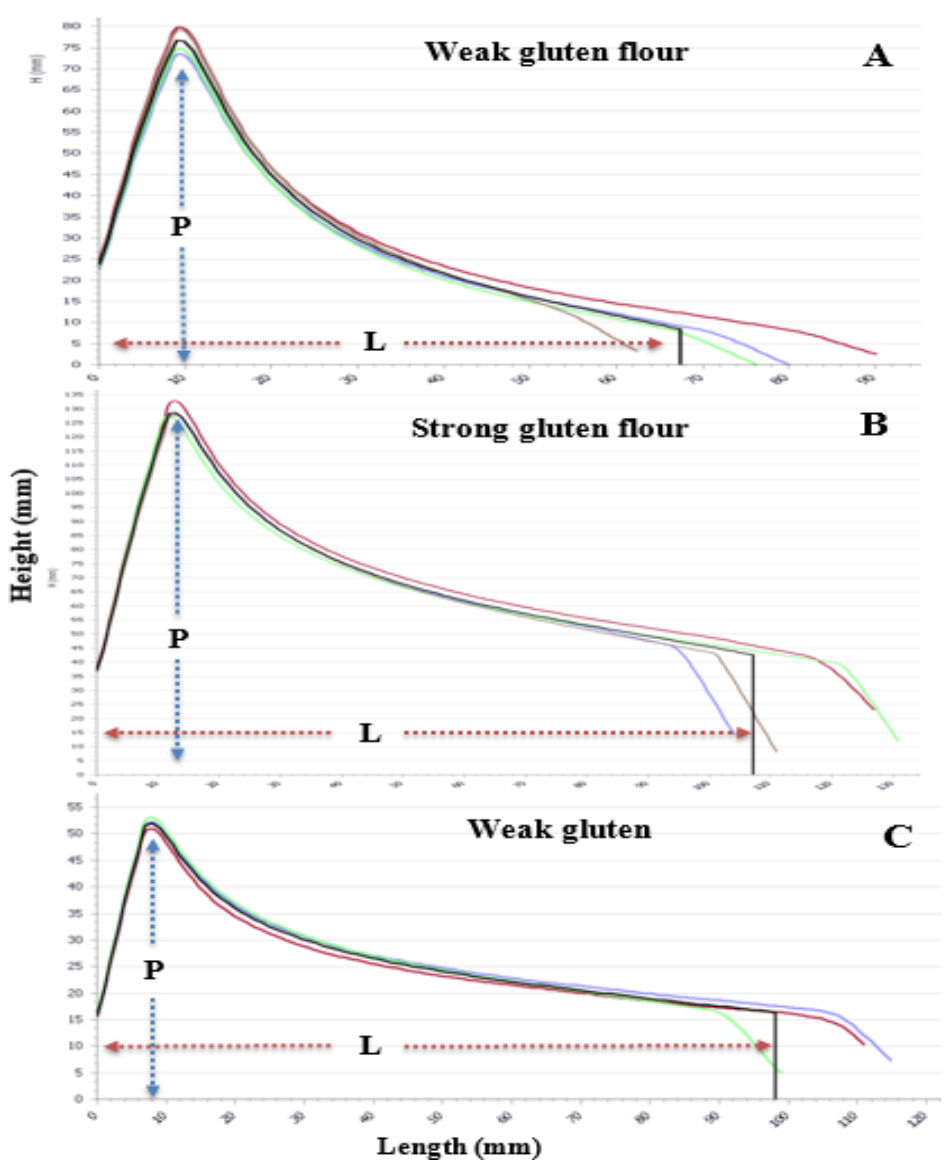

Fig. (2): Alveogram of (A) hybridized bread wheat Line148 (L148), (B) radiation mutation bread wheat (M10), (C) control bread wheat Gemmeiza $11(\mathrm{Gm11})$, (P) value of dough resistance to deformation or tenacity, (L) value of extensibility of dough. 


\section{Conclusion}

Rheological characteristics of wheat flour dough were affected by different wheat varieties/genotypes. The induction of mutation in wheat by gamma radiation, used in wheat breeding programs, seems to be a promising treatment. Where, parameters such as farinograph water absorption and dough stability in addition to alveograph tenacity, extensibility, swelling index, dough energy showed significant increasing. Furthermore, the breeding program to be successful quality wise, the breeder needs to work with a cereal chemist who manages a laboratory that has all the equipment needed to screen breeding lines at the different stages of their development in the breeding process. Breeders handle thousands of lines per year and they need to be whittled down to the few lines that may end up as varieties. Consequently, M10 was the best promising line in the most experiments under study.

\section{Acknowledgments}

The authors wish to express their gratitude to International Company for Milling - Ghareeb Group and Egyptian Millers Company for supporting the facilities for this research work and technical assistance.

\section{References}

1. Bockstaele, F. V., De Leyn, I., Eeckhout, M. and Dewettinck, K. Rheological properties of wheat flour dough and the relationship with bread volume. i. creep-recovery measurements. Cereal Chem., 85: 753 - 761 (2008).

2. Živančev, D., Torbica, A., Mastilović, J., Hristov, N. Technological quality of wheat cultivars from new breeding program (ZVEZDANA and NS3-5299/2) and comparison to the technological quality of wheat cultivars commonly used in agricultural practice (NS RANA 5, LJILJANA, POBEDA AND EVROPA 90), Food Processing, Qual. Saf., $53-58$ (2009).

3. Constantinescu, G., Dabija, A., Buculei, A. and Rebenciuc, I. Evaluation of wheat quality using modern methods. J. Agroal. Proc. Technol., 17: 469 - 472 (2011).

4. Abbasi, H., Emam-Djomeh, Z. and Seyedin, S. M. Application of artificial neural network and genetic algorithm for predicting three important parameters in bakery industries. Inter. J. Agricul. Sci. Res., 2: 51 - 64 (2011).
5. Amjid, M. R., Shehzad, A., Hussain, S., Shabbir, M. A. and Khan, M. R. A Comprehensive review on wheat flour dough rheology. Pak. J. Food Sci., 23: 105 - 123 (2013).

6. Hadnadev, T. D., Pojić, M., Hadnadev, H. and Torbica, A. The role of empirical rheology in flour quality control. Pp. 335 - 360. In: Akyar, S. (Ed.). Wide Spectra of Quality Control (2011)

7. Diosi, G., More, M. and Sipos, P. Role of the farinograph test in the wheat our quality determination. Intern. Sci. J. Sapi. Univ., 8: $104-110$ (2015).

8. Hrušková, M. and Famêra, O. Prediction of wheat and flour Zeleny sedimentation value using NIR technique. Czech J. Food Sci., 21: 91 - 96 (2006).

9. AACC. Approved Methods of the AACC. $10^{\text {th }}$ edition. American Association of Cereal Chemists (AACC), Saint Paul, Minnesota (2000).

10. SAS. Statistical Analysis Systemuser's guide, SAS Institute Inc. Cary, NC, USA (2009).

11. Shelton, D. Wheat and flour testing methods: A guide to understanding wheat and flour quality. Wheat Marketing Centre (WMC), Inc., Portland, Oregon, USA, Pp. 73 (2004).

12. Stathopoulos, C. E., Tsiami, A. A., Schofield, J. D. and Dobraszczyk, B. J. Effect of heat on rheology, surface hydrophobicity and molecular weight distribution of glutens extracted from flours with different breadmaking quality. J. Cereal Sci., 47: $134-143$ (2008).

13. Aprodu, I., Banu, I., Stoenescu, G. and Ionescu, V. Effect of the industrial milling process on the rheological behavior of different types of wheat flour. Scient. Study Res., 11: 429 - 437 (2010).

14. Moradi, V., Khaneghah, A. M., Fallah, A. and Akbarirad, H. Rheological properties of wheat flour with different extraction rate. Inter. Food Res. J., 23: 1056 - 1061 (2016).

15. Blakeney, A. B., Cracknell, R. L., Crosbie, G. B., Jefferies, S. P., Miskelly, D. M., O’Brien, L., Panozzo, J. F., Suter, D. A. I., Solah, V., Watts, T., Westcott, T. and William, R. M. Understanding of wheat flour quality: A basic introduction to Australian wheat quality. Grains research and development corporation (GRDC), Kingston, ACT 2604, Australia, Pp. 40 (2009). 
16. Stoenescu, G., Ionescu, V. S., Banu, I. Rheological properties of the wheat flour supplemented with different additives. Food Technol., 35: 54 - 62 (2011).

17. Shelton, D. Wheat and flour testing methods: A guide to understanding wheat and flour quality, version 2, wheat marketing center (WMC), Inc., Kansas State University, USA (2008).

18. Teixeira, C. A. H. M., Inamura, P. Y., Uehara, V. B., Mastro, N. L. D. Gamma radiation influence on technological characteristics of wheat flour. Rad. phys. chem., 81: 1160 - 1162 (2012).

19. Hayta, M. and Schofield, J. D. Heat and additive induced biochemical transitions in gluten from good and poor bread making quality wheats. J. Cereal Sci., 40: $245-256$ (2004).

20. Sliwinski, E. L., Kolster, P., Prins, P. A. and Van Vliet, T. On the relationship between gluten protein composition of wheat flours and large-deformation properties of their doughs. $J$. Cereal Sci., 39: 247 - 264 (2004).

21. Akubor, P. I. and Ukwuru, M. U. Functional properties and biscuit making potential of soybean and cassava flour blends. Plant Foods Hum. Nutr. 58: 1 - 12 (2003).

22. Kenny, S., Wehrle, K., Auty, M. and Arendt, E. K. Influence of sodium caseinate and whey protein on baking properties and rheology of frozen dough. Cereal Chem. J., 78: $458-463$ (2001).

23. Paraskevopoulou, A., Provatidou, E., Tsotsiou, D. and Kiosseoglou, V. Dough rheology and baking performance of wheat flour-lupin protein isolate blends. Food Res. Inter., 43: 1009 - 1016 (2010).

24. Hefnawy, T. M. H, El-Shourbagy, G. A, Ramadan M F. Impact of adding chickpea (Cicer arietinum L.) flour to wheat flour on the rheological properties of toast bread. Inter. Food Res., J. 19: 521 - 525 (2012).

25. Aboaba, O. O. and Obakpolor, E. A. The leavening ability of baker's yeast on dough prepared with composite flour (wheat/cassava). Afr. J. Food Sci., 4: 325 - 329 (2010).

26. Zaidel, D. N. A., Chim, N. L., Yusof, Y. A. A review of rheological properties and measurements of dough and gluten. J. Appl. Sci., 10: 2478 - 2490 (2010).
27. Ooms, N. and Delcour, J. A. How to impact gluten protein network formation during wheat flour dough making. Current opinion in food science, 25: 88 - 97 (2019).

28. Campbell, G. M. and Shah, P. Entrainment and disentrainment of air during bread dough mixing and their effect on scale-up of dough mixers. In: Campbell, G.M., Webb, C., Pandiella, S.S. and Niranjan, K. (Eds.), Bubbles in Food. American Association of Cereal Chemists, St Paul, Minnesota, USA (1999).

29. Dobraszczyk, B. J. and Salmanowicz, B. P. Comparison of predictions of baking volume using large deformation rheological properties. J. Cereal Sci., 47: 292 - 301 (2008).

30. Hrušková, M., Svec, I. and Jirsa, O. Correlation between milling and baking parameters of wheat varieties. J. Food Engi., 77: 439 - 444 (2006).

31. Tomic, J., Torbica1, A., Popovic, L., Strelec, I., Vaštag, Ž., Pojic1, M., Rakita, S. Albumins characterization in relation to rheological properties and enzymatic activity of wheat flour dough. J. Agricul. Sci. Technol., 17: 805 -816 (2015).

32. Wang, J., Rosell, C. M., Benedito, B. C. Effect of the addition of different fibers on wheat dough performance and bread quality. Food Chem., 79: 221 - 226 (2002).

33. Indrani, D. R., Manohar, S., Rajiv, J. and VenkateswaraRao, G. Alveograph as a tool to assess the quality characteristics of wheat flour for parotta making. J. Food Engi., 78: $1202-$ 1206 (2007).

34. Dubois, M., Canadas, D., Despres-Pernot, A. G., Coste, C. and Pfohl-Leszkowicz, A. Oxygreen process applied on nongerminated and germinated wheat: Role of hydroxamic acids. J. Agric. Food Chem., 56: 1116 - 1121 (2008).

35. Bordes, J., Branlard, G., Oury, F. X., Charmet, G. and Balfourier, F. Agronomic Characteristics, Grain Quality and Flour Rheology of 372 Bread Wheats in a Worldwide Core Collection. J. Cereal Sci., 48: $569-579$ (2008). 